\title{
DIVERSITY AND FIRM PERFORMANCE: AN ANALYSIS OF DIFFERENT LEVEL OF MANAGEMENT COMPOSITION
}

\author{
Byeongyong Paul Choi, School of Business, Howard University, Washington DC, USA \\ Jin-Gil Jeong, School of Business, Howard University, Washington DC, USA
}

dx.doi.org/10.18374/JIFE-13-1.18

\begin{abstract}
Using unique data for a ten-year period, this article examines the impact of diversity on firm performance based on eight different levels of management composition. The demographic variables include total minorities, female minorities, minority managers, female managers, minority professionals, female professionals, minority sales workers, and female sales workers. The results of this research show that diversity strategy is successful at the macro level. However, weak support on the importance of workforce diversity is presented at the micro level.
\end{abstract}

Keywords: Firm Performance, Tobin's q, Diversity, Demographic Variables 